\title{
Study of Marketing and Processing of Mango Enterprise with a View to Reduce Wastage Among Local Mango Producers in Zambia
}

\author{
Article by Mukonde Siafunda \\ Management, Texila American University \\ E-mail: mukondes65@gmail.com
}

\begin{abstract}
Mangifera indica L., is one of the tropical fruit trees grown in Zambia. The mango fruit produced in rainy season go to waste. In order to reduce the waste, a business model must be employed to use this mass production into an opportunity. A study was undertaken on how the business model would play a big role in providing markets for the mango fruits in Zambia. The researcher identified the marketing players in the industry such as processing companies, producers, and traders. Through the literature review and the study, it was found that the mango processing enterprise is profitable because it has a huge market within Zambia especially in the slack period of mango production. Due to competition for these outlets, the processing companies will need strategic planning with sound marketing strategies. This loss can go up to 30 or $40 \%$. With a bleak possibility to store mangoes locally, smallholder farmer has to sell his harvest at the time that the market is flooded and the prices are on its lowest. (GVCT 2016). This also result into the loss of contribution to the economy of Zambia that is predominantly agriculturally based. This study looked at three marketing players and profitability and this showed that the producers have a net profit margin of $18.34 \%$, the trader at $19.45 \%$ and the processor at $34.1 \%$. This shows that the processor would help to reduce wastage and at the same time be able to make profits out of the business model.
\end{abstract}

Keywords: Market players, processing, net-profit margin, wastage.

\section{Introduction}

Agricultural products processing in Zambia is still in its infancy and this is more evident in the fruit production and processing industry. A few companies have processing plants where harvested or slaughtered farm produce are processed into marketable and edible products in well presentable packaging. The most popular processors are millers that process maize meal. The fruit processing in Zambia is not well developed. Zambia produces a fair share of fruits and the most produced is Mango fruit. Mango fruits are produced in abundance in Zambia and this fruit goes to waste every year.

Mango (Mangifera indica L.) is a tropical fruit tree that is widely grown in Zambia. Its fruit is a source of pre-biotic dietary fiber, vitamins, minerals, and poly-phenolic flavonoid antioxidant compounds. Mango fruit is one of the most popular, nutritionally rich fruits with unique flavor, fragrance, taste, and heath promoting qualities that could promote a health nation especially in children and lactating mothers.

The tree is believed to be originating in the sub-Himalayan plains of the Indian subcontinent. Botanically, this exotic fruit belongs to the family of Anacardiaceae, a family that also includes numerous species of tropical fruiting trees in the flowering plants such as cashew, pistachio. Its scientific name is Mangifera Indica $L$.

Mango is not just a fruit but it is one of the most cherished foods in traditional Zambia. The fruit is at the centre of rural Zambian society as a source of food that is so anticipated and cherished, which can also be processed into juice and other products such as jam (hunger for culture, 2013). Essentially a prime table fruit, mango pulp is perfectly suited for conversion to juices, nectars, drinks, jams, fruit cheese or to be had by itself or with cream as a superb dessert. It can also be used in puddings, bakery fillings, and fruit meals for children, flavours for food industry, and also to make the most delicious ice cream and yoghurt. While the raw fruits are utilized for products like chutney, pickle, amchoor (mango powder), green mango beverage, etc. ripe ones are used in making pulp, juice, nectar, squash, leather, slices, etc. Green or ripe mangoes may be used to make relish (Morton, 1987). In Zambia, it is mostly 
ISSN: $2520-310 \mathrm{X}$

eaten in its raw unprocessed form in both urban and rural areas. The farmers and traders from rural areas where there is mass production, bring the mango fruit into town centres especially the cities Lusaka (capital city of Zambia) to sell to urban people.

In the months of October to January, the Mango fruits is in abundance in Zambia. The fruit goes to waste every year. All the provinces of Zambia produce in such abundance that farmers and those with mango trees let the fruit to rot and thrown away. They only manage to eat small quantities of the fruit with their families. As stated, the fruit become garbage as not all of it is consumed. This is an opportunity for the business enterprises to utilize and process the fruit into juices, drying, mango chips and any other products that would be sold on the market.

\section{Purpose of the study}

With this in mind, the researcher undertook a study to establish the marketing and profitability of producing and processing the mango fruit in a view of reducing wastage and provide solutions in the business processing model. The following are the main objectives of the study:

i) To analyze the profitability of Mango production and problems in mango marketing

ii) To examine the role of producers, traders and processors in Mango value chain process

iii) To offer suggestions on the measures to improve the marketing efficiency of producers and processors

\section{Problem statement}

Mango trees are widely grown in the Zambia, however, there is a lot of wastage where they rot on the ground or buried because of lack of storage technology, lack or few fruit processing cottage industry and no value addition to the fruit. This is as a result of inadequate fruit processing technology knowledge amongst small scale farmers. (ZNFU, 2014). Mango is a perishable agricultural product that needs to be well stored and processed to add value to it in order to get profit out of the enterprise. With the inability to process mangoes and other fruit on local bases, a lot of the yearly production is lost. This loss can go up to 30 or $40 \%$. With a bleak possibility to store mangoes locally, small farmer has to sell his or her harvest at the time the market is flooded and the prices are on its lowest. (GVCT 2016)

With all these limitations, the farmers have to cultivate and earn profit. The financial constraints and lack of adequate infrastructure for marketing of Mango are some of the problem areas. The limitations of the off-takers especially the processors need to be explored further.

\section{Existing solutions}

The marketing channels for the mangoes range as follows:

- Family/locally eaten and Preservation/drying at village level

- Mango trading from rural to urban areas

- Juices, Jam processing from processing companies

- Exporting

\section{Best option}

There is a huge market for mango juices and jams in Zambia. The value addition i.e. packaging, increase in shelf life and attracting organized marketing, need to be explored in Zambia. The urban population has changed their taste to consume pure juices other than consuming a raw mango from a tree. In addition, the indigenous knowledge on drying and preserving fruits such as mangoes has gone down due to change of life styles and consumer taste. Coupled with the limitations in exporting the indigenous mangoes makes local marketing avenues attractive to the industry. The study identifies the following marketing chains in the country:

i) Producer to villagers/rural (consumers) people for home consumption

ii) Producer to trader in open markets in urban areas

iii) Producer/Trader to processing unit/companies

\section{Limitations}

Seasonality of the mango production that lead to low prices at the time of mass production is at the base of mango value chain limitations. The mango fruit is produced between October and January each 
year. This results in the fact that most of this fruit produced at this time go to waste due to lack of storage facilities that would keep the fruits for a long time. In addition, transport costs may be incurred in the process of following the urban markets and this can render distortion of prices. Lack of investment programs in establishment of processors has led to limiting the marketing avenues available for the mango producers. In addition, there are no organized markets for Mangoes in all the provinces of Zambia.

\section{Achievements}

As a country there is still a lot of struggle to harness the mass production of the mangoes produced in Zambia. However, there are two processors which are well known in Zambia namely CHANKWANKWA farms and Food Processors limited and COMACO. CHANKWANKWA Farms and Food Processors has since been making mango jams and juice while COMACO has been drying mangoes for use later in the season.

Some of the producers have started producing exotic cultivars that have preferred qualities such as larger sizes, juicy and very sweet varieties, in order to harness the export markets.

\section{Methods}

The study undertook a survey in the high producing central region of Zambia. Qualitative and quantitative data was collected based on informal interview of key respondents, and structured interviews of producers, traders and processors. The Producers are defined as those who grow mangoes and do not engage in trading of the product. Traders are those who engage in bulk buying and take to large markets mostly in urban areas. Processors are those who add value to the mangoes through processing mangoes into dried fruits, mango juice and mango jam for both local and export markets.

\section{Primary data collection}

Primary data was collected using interview and well-structured questionnaires from 50 mango producers and Seven (07) traders. The study only managed to interview only one processor namely CHANKWANKWA Farms and Food Processors Limited who is found in the Central Region of Zambia.

Purposive Random sampling was done and the study settled for a sample size of 50 Mango producers that were grouped in five (5) focus group discussions to establish the avenues of sell and the profitability of mango production and other qualitative data. In the same vein, individual interviews were conducted to the seven (7) Mango traders to establish the marketing channels/avenues that will reduce the wastage. Only one processor was available to be interviewed for the study to establish the profitability of the mango processing industry.

\section{Secondary data collection}

Secondary data was collected from the internet, journals of previous papers on mango value chains, offices of government departments such as Ministry of Agriculture, Ministry of Commerce and Trade. Central Statistics Office and local libraries were some of the places where secondary data was collected.

\section{Quantitative analysis}

Quantitative analysis was done through collecting data through a survey from the producers, traders and processors in Central Region. This was done in order to give an indication producing, trading and processing benefits and problem encountered in the Mango value chain.

The researcher prepared the trading, profit and loss accounts in order to establish the profitability of both producing, selling and processing mango. This is shown in table on page 14 in this paper. The Net Profit Margin was calculated by dividing Net Profit by Total sales multiplied by hundred to find the percentage.

\section{Qualitative analysis}

Qualitative data was collected from the interview in looking the processes involved in mango production, trading and processing. The researcher was able to analyze the interviewee stories and was 
ISSN: $2520-310 \mathrm{X}$

able to come to a conclusion of what happens in the mango value chain. This is evident in the results that are outlined in the following section

\section{Results}

After the interviews it was found that each group of participants had particular results:

i) Focus group discussion for the producers,

- There is so much loss at the farm level. Mangoes rot at the farm without any meaningful storage to prevent rotting

- The production practices are not up to standard to get maximum yields and hence get maximum profits

- The producer always relies on the trader to purchase the commodity. They do not pursue the central urban markets

- The cost of producing mango fruit is low for the producer

- There are no organized markets where the producer is able to take their produce for sale.

- The mango fruit is only produced once a year in October to January.

- The producer households enjoy the mango fruit

- Producers do not keep proper records for the mango sales at farm level

- The Net Profit Margin is low at $18.34 \%$

i) Individual Trader interview findings

- They struggle with proper storage of Mango fruit

- They have to incur storage cost to redeem some of the mango fruits they buy/sale

- The transportation cost is very high

- They get mangoes from far remote areas that leads to risk of rotting during transportation

- There are no organized market for the traders

- They incur utility bills such as electricity

- They have difficulties in setting prices

- There are so many on the market during the production season

- The Net Profit Margin for traders is at $19.45 \%$

ii) Mango Processor Company

- The processor monopoly of buying raw mangoes at a competitive price

- Incur high utility bills such as electricity and water

- The processing costs are very high

- It needs technical knowhow to process the mangoes to the required standards

- The Net Profit Margin is relatively above Central Statistics Office (CSO) Standards at $34.10 \%$

- Faces competition in supermarkets for juice and jam market (exotic and carbonated products)

\section{Discussion}

This paper discusses the results of the mango profitability of the mango enterprise in the view of the mango wastage during the production period.

The producer has many challenges in the production of the mango fruit. They are not able to produce to according to standards that may attract high prices. The producer is at a disadvantage in terms of farm gate pricing because the farm gate price $50 \%$ less than the urban market price. This makes mango fruit sale unattractive business venture to the producer. Producers were also not able to keep proper records of how much they were harvesting, selling and total costs incurred during production. This then makes them vulnerable and may not know how much net profit margin they could make after selling mangoes. This also results in not seeing the profitable value of the mangoes that it can improve their livelihoods.

In addition, the producer does not have storage facilities that would allow them to store mangoes until opportune time to increase prices. This then reduces the value of mangoes. The prices become very low at the time of peak production in the season. In this case the wastage is so high that the mango fruit rot in the fields. 
At the intermediary level or the trader level, the trader is able to look for available markets in the urban centers where he doubles the prices of mangoes in order to cover the high transport expenses incurred. The trader gambles with the perishability aspect of mangoes twofold: a) as the trader travels long distances from remote rural areas to urban close to $200 \mathrm{~km}$ to $500 \mathrm{~km}$ and the mangoes become overripe and some rot on the way; b) when the trader arrives at the market, they usually find a mango flooded market. This results in not selling in quantities anticipated. Sometime half of the ten (10) truck load is not sold and go to worst. There are limited cold room storage facilities that would accommodate the mango trader merchandize. Again, wastage haunt the mango marketing. The trader has a net profit margin above the producer at $19.45 \%$. However, this is lower than the Central Statistics Office (CSO) acceptable Net Profit Margin of about 30\%.

The processors soars above the CSO acceptable Net Profit Margin and are at 34.1\%. This gives motivation for the processors to establish fruit processing industry in Zambia. The processors also enjoy monopoly in obtain raw materials. They are able to dictate prices to both the trader and the producers. This is because there no many fruit processing companies in Zambia. However, the processor is not without challenges. The processor faces competition in the marketing value added products. The imported processed fruit juices, blends, carbonated drinks and also the fruit jams have flooded the Zambian markets from the neighboring and other countries. The most popular are those from Tanzania and South Africa.

With this in mind, the processor needs to employ marketing strategies that will attract customers thereby obtain high mango product sales

Looking at the need and the benefits that Mango provides to the health of a person, it is possible that an organization or a company would venture into the mango processing enterprise and be able to market the mango products such as juices, jams, pulp etc., for both domestic and international markets. A market consists of all the potential customers sharing a particular need or want who might be willing and able to engage in exchange to satisfy that need or want (Philip Kotler). For this value chain, there are particularly three needs that a mango processing enterprise would be addressing namely a) Providing market for the fresh mangoes that goes to waste in time of plenty, b) provision of value-added mango products for example in dried form during slack periods and c) providing income to mango farmers. With these needs, mango processed products will find market. This will result in provision of employment and increase in income generation in the rural areas. Another benefit is that, the more demand from processing companies, the more will be the need to plant more mango trees that would also be beneficial in reducing climate change effects in Zambia.

The organization or a company that would venture into this business would be required first of all to make a strategic plan on how the company is going to carry out their business. The organization will have to look at the vision and mission statements in order to have a road map on how they will meet their objectives. This kind of company would perhaps have a vision that will help the company to be the leading company in providing market for fresh mangoes. To ensure that they select and execute the right activities in the Mango processing, marketers must give priority to strategic planning in three thematic areas namely a) managing a company's businesses as investment portifolio, b) assessing each business's strength by considering the market's growth rate and the company's position and fit it in that market, and c) establishing a strategy. The company must develop a game plan for achieving each business' long-term objectives or mission statements.

A marketing strategy is a business's overall game plan for reaching people and turning them into customers of the product or service that the business provides. The marketing strategy of a company contains the company's value proposition, key marketing messages, information on the target customer and other high-level elements. The marketing strategy informs the marketing plan, which is a document that lays out the types and timing of marketing activities. A company's marketing strategy should have a longer lifespan than any individual marketing plan as the strategy is where the value proposition and the key elements of a company's brand reside. The marketing strategy may also be absorbed upwards into the corporate value statements and other strategy documents. A marketing strategy grows out of a company's value proposition. The value proposition summarizes the competitive advantage a company has in its market. The value proposition usually provides the key message for all marketing. A company is never creating a marketing strategy from scratch. They start with the value proposition and distill the 
key marketing message(s) from that. Once the value proposition is succinctly stated, the hard work is done. Any marketing asset, from a print ad design to a social media campaign, can be judged by how well it communicates the value proposition. To further the efficiency of marketing efforts, market research can be added to the marketing strategy for the purpose of identifying untapped audiences or refining the target consumer. In addition, an overall goal for the marketing strategy can be set, with all the subsequent marketing plans inheriting the responsibility for delivering on it. These can be concrete, bottom-line goals such as increasing sales or something less direct like climbing the ranking of trusted providers within the industry. https://www.investopedia.com/terms $/ \mathrm{m} /$ marketing-strategy.asp In this paper we will discuss the key strategies that could be used in a mango processing enterprise. As far as customers are concerned there are three elements to address that is

a) Customer value: difference between the values that the customers gain from owning and using a product versus the cost of obtaining the product. The mango customers will expect the real taste of mangoes in whatever state it is presented.

b) Customer Satisfaction: the extent to which a product's perceived performance in delivering value matches a buyer's expectations

c) Quality: the characteristics of a product or service that bear on its ability to satisfy stated or implied customer needs. For example, in the Mango processing industry, the customer will expect quality mango jams and pulp from carefully processed fresh mangoes.

Marketing management employs tools from economics and competitive strategy to analyze the industry context in which the firm operates. These include Porter's five forces, analysis of strategic groups of competitors, value chain analysis and others. In competitor analysis, marketers build detailed profiles of each competitor in the market, focusing on their relative competitive strengths and weaknesses using SWOT analysis. For example, Chankwakwa Farms and Food Processors should be able to analyse their competitors such as COMACO food processors, SYLVA Catering and food processors before entering the market. This helps in properly analyse the markets for the mangoes. The Marketing manager using the strategic plan must look elsewhere for market including international markets. Marketing managers will examine each competitor's cost structure, sources of profits, resources and competencies, competitive positioning and product differentiation, degree of vertical integration, historical responses to industry developments, and other factors.

Marketing management often conduct market research and marketing research to perform marketing analysis. Marketers employ a variety of techniques to conduct market research, but some of the more common include Qualitative marketing research, such as focus groups and various types of interviews and also Quantitative marketing research, such as statistical surveys. After the market research, the company must then employ technics that will help in establishing an enterprise and be able to penetrate the market. One of the tactics the marketer may have is market segmentation that helps to target the customer into groups that will be able to buy the product. In this case, a mango processor will segment the food industries that might process much more.

The marketing strategies will include and not limited to the following tools that will help the firm to be able to sell more. These are called the 7 Ps of marketing namely Product, price, promotion, people, physical evidence, place and processes. For the enterprise to survive in their marketing strategy and ultimately in the strategic planning and the set-out goals that encompasses profitability, the marketer should make sure that the market mix of the 7Ps is taken care of. For example, promotion of the product would be in many ways such as branding the product and advertise in a way that the customers are able to find the product. The enterprise must be able to communicate to the customers what they are selling and the benefits that are derived from the product. For the mango enterprise we have already seen how beneficial the mango fruit is and those benefits must be communicated to the customers and consumers of the products. Promotion is also embedded in the digital marketing where for example the media is used to communicate to customers the potential and goodness of the product. The computer age has made it easier to sell on internet and to all places. The place now is wherever someone is able to communicate on internet they are able to access a product. This works to reach out almost all people who is able to access social media. 
Chankwakwa Farms and Food processors have branded their products and according to proprietor, branding helped to sell and penetrate the market that was already had a variety of jams and juices. This is seen in the figure 4 (with courtesy of SAFE project and the Chankwakwa Farms and Food Processors) https://www.agrilinks.org/sites/default/files/resource/files/chankwakwa_5.25.17.pdf

\section{Conclusion}

This paper concludes that the mango processing industry may be the answer to reducing mango fruit wastage. The researcher analyzed the findings and they revealed that it is profitable to process mangoes than to just trade without adding value to the mango fruit hence reducing on the wastage of the fruit. The results also show that proper storage is very vital in the mango trading venture as mangoes are a perishable fruit. Since there are few mango processing companies, this paper recommends that there should be more investments done to establish processing industries to curb the mango wastage in the country. This will also reduce processing companies' monopoly when buying raw mangoes and buy at competitive prices that will give a win-win situation to all market players. When organized markets and processing companies are established, the seasonality limits for all the market players will be reduced in that cold room storage facilities will be able to keep mangoes even off-season. This mango processing business model brings to the fall numerous benefits that include, increase in incomes, health benefits to the local people, reduction of climate change effects through mango plantations, and reduction of mango wastage through utilizing every fruit for processing. The business model is self-sustaining because the proprietor is attracted by the profitability of the enterprise and mops up the mangoes that would have gone to waste in the process. 


\section{Tables and figures}

Table 1. Focus group discussion interviews for 70 producers

\begin{tabular}{|c|c|c|c|c|c|c|c|}
\hline \multirow{3}{*}{$\begin{array}{l}\text { Detailed items } \\
\text { Cost of Production } \\
\end{array}$} & \multicolumn{7}{|c|}{ Sampled producer groups/average findings (ZMW) } \\
\hline & FDG 1 & FDG2 & FDG3 & FDG4 & FDG5 & \multirow{2}{*}{ Totals } & \multirow{2}{*}{ Average } \\
\hline & & & & & & & \\
\hline 230crates/acre & 180.00 & 250.00 & 210.00 & 100.00 & 315.00 & $1,055.00$ & 211.00 \\
\hline Labour cost & 500.00 & 715.00 & 655.00 & 230.00 & 836.00 & $2,936.00$ & 587.20 \\
\hline $\begin{array}{l}\text { Nursery } \\
\text { establishment costs }\end{array}$ & 200.00 & 85.00 & 140.00 & 110.00 & 425.00 & 960.00 & 192.00 \\
\hline Cost of irrigation & 150.00 & 120.00 & 105.00 & 50.00 & 155.00 & 580.00 & 116.00 \\
\hline Cost of harvesting & 400.00 & 348.00 & 500.00 & 205.00 & 480.00 & $1,933.00$ & 386.60 \\
\hline $\begin{array}{l}\text { Cost of } \\
\text { packaging/crates }\end{array}$ & 250.00 & 557.00 & 312.00 & 130.00 & 450.00 & $1,699.00$ & 339.80 \\
\hline Cost of wastage & 630.00 & $1,050.00$ & 750.00 & 375.00 & $1,350.00$ & $4,155.00$ & 831.00 \\
\hline $\begin{array}{l}\text { Number of crates } \\
\text { wasted }\end{array}$ & 42.00 & 70.00 & 50.00 & 25.00 & 90.00 & 277.00 & 55.40 \\
\hline Miscellenaous & 105.00 & 150.00 & 125.00 & 80.00 & 200.00 & 660.00 & 132.00 \\
\hline \multirow[t]{2}{*}{ Total Cost } & $2,235.00$ & $3,025.00$ & $2,587.00$ & $1,180.00$ & $3,896.00$ & $12,263.00$ & $2,452.60$ \\
\hline & & & & & & & - \\
\hline Income generated & & & & & & & - \\
\hline $\begin{array}{l}\text { Number crates } \\
\text { sold/15 per crate }\end{array}$ & & & & & & & - \\
\hline Sale of mangoes & $2,700.00$ & $3,750.00$ & $3,150.00$ & $1,500.00$ & $4,725.00$ & $15,825.00$ & $3,165.00$ \\
\hline \multirow[t]{2}{*}{ Total sales } & $2,700.00$ & $3,750.00$ & $3,150.00$ & $1,500.00$ & $4,725.00$ & $15,825.00$ & $3,165.00$ \\
\hline & & & & & & & - \\
\hline
\end{tabular}




\begin{tabular}{|l|c|c|c|c|c|c|c|} 
Net Profit & $\mathbf{4 6 5 . 0 0}$ & $\mathbf{7 2 5 . 0 0}$ & $\mathbf{5 6 3 . 0 0}$ & $\mathbf{3 2 0 . 0 0}$ & $\mathbf{8 2 9 . 0 0}$ & $2,902.00$ & 580.40 \\
\hline $\begin{array}{l}\text { Net Profit Margin } \\
(\%)\end{array}$ & & & & & & & \\
\hline
\end{tabular}

Table 2. Individual interviews for 10 producers' findings

\begin{tabular}{|l|l|l|l|l|l|l|l|l|}
\hline \multirow{2}{*}{ Detailed items } & \multicolumn{7}{|l|}{ SAMPLED MANGO TRADERS (ZMW) } \\
\cline { 2 - 9 } & $\begin{array}{l}\text { TRADER } \\
\mathbf{1}\end{array}$ & $\begin{array}{l}\text { TRADER } \\
\mathbf{2}\end{array}$ & $\begin{array}{l}\text { TRADER } \\
\mathbf{3}\end{array}$ & $\begin{array}{l}\text { TRADER } \\
\mathbf{4}\end{array}$ & $\begin{array}{l}\text { TRADER } \\
\mathbf{5}\end{array}$ & $\begin{array}{l}\text { TRADER } \\
\mathbf{6}\end{array}$ & $\begin{array}{l}\text { TRADER } \\
\mathbf{7}\end{array}$ & Average \\
\hline Cost incurred & & & & & & & \\
\hline Rent/storage & 300 & 500 & 200 & 250 & 325 & 440 & 275 & 2290 \\
\hline Electricity & 100 & 125 & 110 & 90 & 100 & 90 & 110 & 725 \\
\hline $\begin{array}{l}\text { Wastage (No. of } \\
\text { crates lost) }\end{array}$ & 150 & 189 & 86 & 116 & 90 & 123 & 68 & 822 \\
\hline $\begin{array}{l}\text { Total cost of } \\
\text { wastage }\end{array}$ & 4500 & 5670 & 2580 & 3480 & 2700 & 3690 & 2040 & 24660 \\
\hline $\begin{array}{l}\text { Transportation } \\
\text { cost }\end{array}$ & 600 & 550 & 500 & 650 & 520 & 490 & 480 & 3790 \\
\hline $\begin{array}{l}\text { No. of crates } \\
\text { bought }\end{array}$ & 800 & 1255 & 580 & 690 & 725 & 966 & 585 & 5601 \\
\hline $\begin{array}{l}\text { Cost of buying a } \\
\text { crate (ZMW15) }\end{array}$ & 12000 & 18825 & 8700 & 10350 & 10875 & 14490 & 8775 & 84015 \\
\hline Total Costs & $\mathbf{1 7 5 0 0}$ & $\mathbf{2 5 6 7 0}$ & $\mathbf{1 2 0 9 0}$ & $\mathbf{1 4 8 2 0}$ & $\mathbf{1 4 5 2 0}$ & $\mathbf{1 9 2 0 0}$ & $\mathbf{1 1 6 8 0}$ & 115480 \\
\hline $\begin{array}{l}\text { Income } \\
\text { generated }\end{array}$ & & & & & & & & \\
\hline No. of crates sold & 650 & 1066 & 494 & 574 & 635 & 843 & 517 & 4779 \\
\hline $\begin{array}{l}\text { Selling price per } \\
\text { crate (ZMW30) }\end{array}$ & 30 & 30 & 30 & 30 & 30 & 30 & 30 & 210 \\
\hline Total Sales & 19500 & 31980 & 14820 & 17220 & 19050 & 25290 & 15510 & 143370 \\
\hline & 2000 & 6310 & 2730 & 2400 & 4530 & 6090 & 3830 & 27890 \\
\hline Net Profit & & & & & & & & \\
\hline
\end{tabular}


DOI: 10.21522/TIJMG.2015.SE.19.01.Art022 ISSN: 2520-310X

\begin{tabular}{|l|l|l|l|l|l|l|l|l|} 
& 58130 & 92170 & 42920 & 50670 & 54100 & 71742 & 43900 & 413632 \\
\hline $\begin{array}{l}\text { Net Profit } \\
\text { Margin (\%) }\end{array}$ & $\mathbf{1 0 . 2 6}$ & $\mathbf{1 9 . 7 3}$ & $\mathbf{1 8 . 4 2}$ & $\mathbf{1 3 . 9 4}$ & $\mathbf{2 3 . 7 8}$ & $\mathbf{2 4 . 0 8}$ & $\mathbf{2 4 . 6 9}$ & $\mathbf{1 9 . 4 5}$ \\
\hline
\end{tabular}


Table 3. Chankwankwa Farms and Food Processors findings and profitability

\begin{tabular}{|l|l|l|}
\hline Item & QUANTITY & TOTAL \\
\hline Mango Pulp 40\% & 2 crates/boxes & ZMW30 \\
\hline Sugar & $2.5 \mathrm{~kg}$ & ZMW35 \\
\hline Electricity & $39.84 \mathrm{kwh}$ & ZMW12.35 \\
\hline
\end{tabular}

\section{Mango jam processing enterprise profitability}

Table 3.1. Costs incurred to produce 50 bottles of Mango Jam

\begin{tabular}{|l|l|l|l|}
\hline DETAILS & QUANTITY & $\begin{array}{l}\text { UNIT } \\
\text { PRICE(ZMK) }\end{array}$ & $\begin{array}{l}\text { TOTAL } \\
\text { AMOUNT(ZMW) }\end{array}$ \\
\hline SALES & $10,500 \times 500 \mathrm{ml}$ bottles & ZMW8/bottle & ZMW84,000 \\
\hline $\begin{array}{l}\text { EXPENSES } \\
\text { VARIABLE } \\
\text { COSTS }\end{array}$ & & & \\
\hline Crates of mango & 420 crates & ZMW15/1 crate & ZMW6,300 \\
\hline Ingredients & Lumpsum & Lumpsum & ZMW1,300 \\
\hline Sugar & $525 \mathrm{~kg}$ & ZMW14/kg & ZMW7,350 \\
\hline $\begin{array}{l}\text { Electricity } \\
\text { (Production and } \\
\text { Storage) }\end{array}$ & $108 \mathrm{kwh} /$ week & ZMW0.31/kwh & ZMW2,594.40 \\
\hline Carriage inwards & - & ZMW180/month & ZMW1,080 \\
\hline Bottles & $10,550 \mathrm{bottles}$ & ZMW1/bottle & ZMW10,550 \\
\hline SUBTOTAL & & & ZMW29174.4 \\
\hline
\end{tabular}

Table 3.2. Income statement for 6 months

\begin{tabular}{|l|l|l|l|}
\hline DETAILS & QUANTITY & $\begin{array}{l}\text { UNIT } \\
\text { PRICE(ZMK) }\end{array}$ & $\begin{array}{l}\text { TOTAL } \\
\text { AMOUNT(ZMK) }\end{array}$ \\
\hline Other expenses & & & \\
\hline Miscellaneous@2\% & Lumpsum & Lumpsum & ZMW1,680 \\
\hline $\begin{array}{l}\text { Advertising and } \\
\text { promotion }\end{array}$ & Lumpsum & Lumpsum & ZMW3,000 \\
\hline Packaging & 50 bottles & Lumpsum & ZMW6,300 \\
\hline $\begin{array}{l}\text { Total Variable } \\
\text { Costs }\end{array}$ & & & (ZMW40,154.40) \\
\hline GROSS PROFIT & & ZMW43,845.6 \\
\hline $\begin{array}{l}\text { FIXED COSTS } \\
\text { pulping machine }\end{array}$ & & ZMW520/year & ZMW260 \\
\hline $\begin{array}{l}\text { Depreciation of } \\
\text { juice fine filter }\end{array}$ & & ZMW1,000/year & ZMW500 \\
\hline $\begin{array}{l}\text { Depreciation of } \\
\text { Mitsubishi Canter }\end{array}$ & & ZMW2,600/year & ZMW1,300 \\
\hline Labour costs & 10 people & ZMW1,050/worker & ZMW10,500 \\
\hline \begin{tabular}{l} 
Carriage outwards \\
\hline
\end{tabular} & & ZMW2,600 \\
\hline
\end{tabular}


DOI: 10.21522/TIJMG.2015.SE.19.01.Art022

ISSN: $2520-310 \mathrm{X}$

\begin{tabular}{|l|l|l|l|}
\hline Total fixed costs & & & ZMW15,160 \\
\hline Total expenses & & & $($ ZMW55,314.40) \\
\hline NET PROFIT & & & ZMW28,685.60 \\
\hline
\end{tabular}

\section{Net profit margin}

Net profit margin $(\%)=($ net profit/sales $) \times 100$

It is required to measure an extent to which a business is generating profits.

$=(\mathrm{ZMW} 28,685.60 / \mathrm{ZMW} 84,000) \times 100=34.1 \%$

\section{Market Player/Net Profit Margin}



Figure 1. Net profit margin for each market player

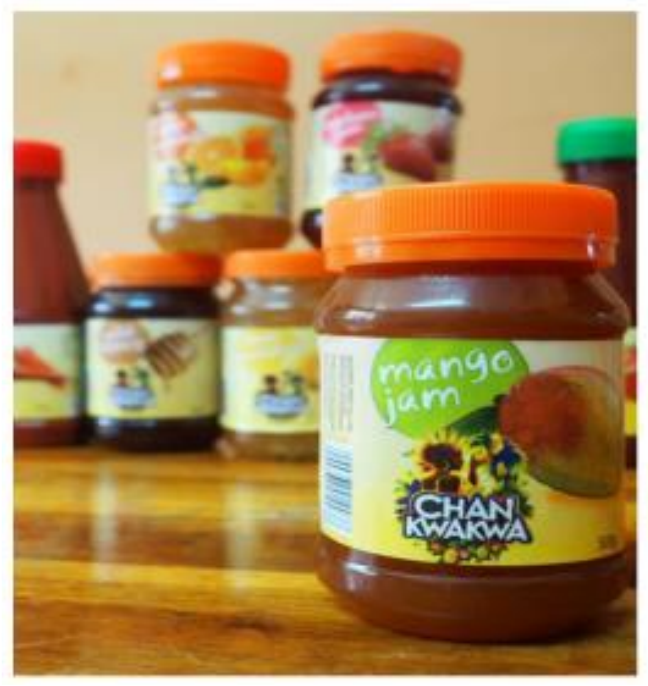

Figure 2. Mango Jam from Chankwankwa farms and Food Processor in Kabwe, Zambia 


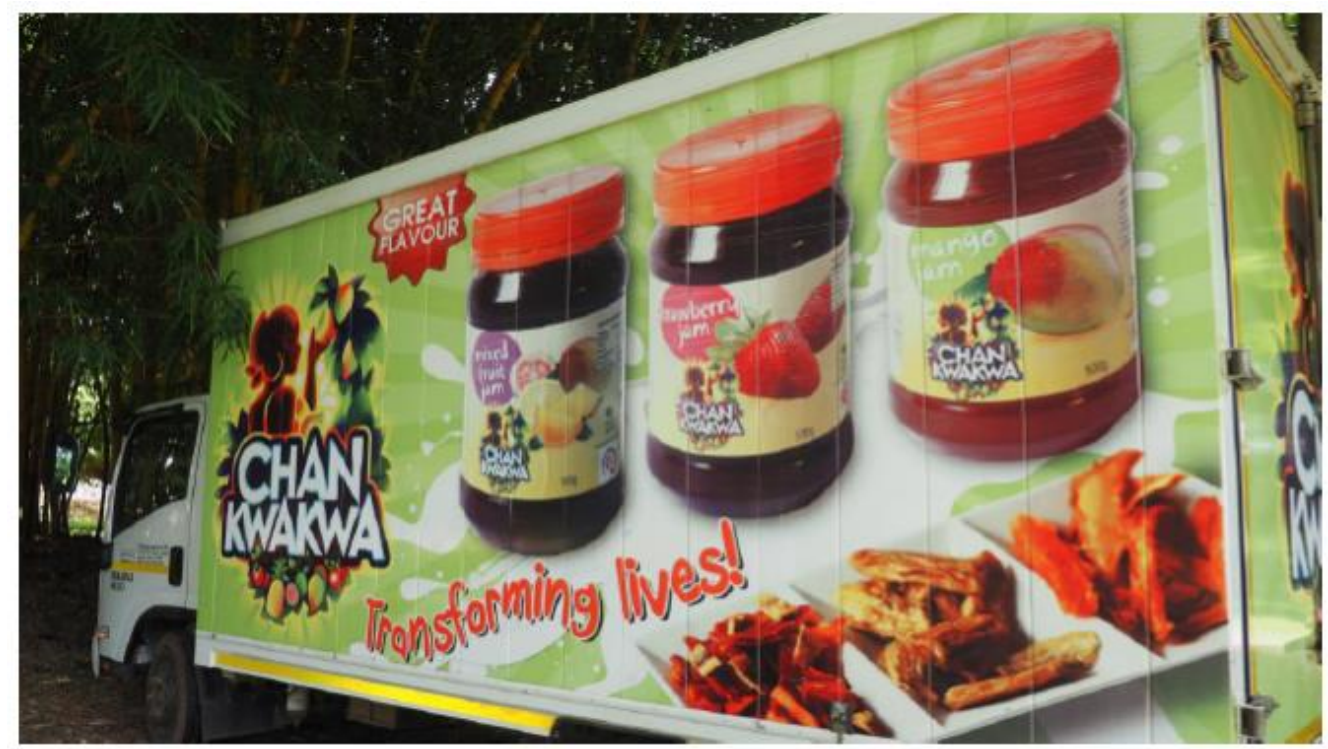

Figure 3. Chankwakwa food processors branding/marketing (courtesy of chankwakwa food processors and the safe project)

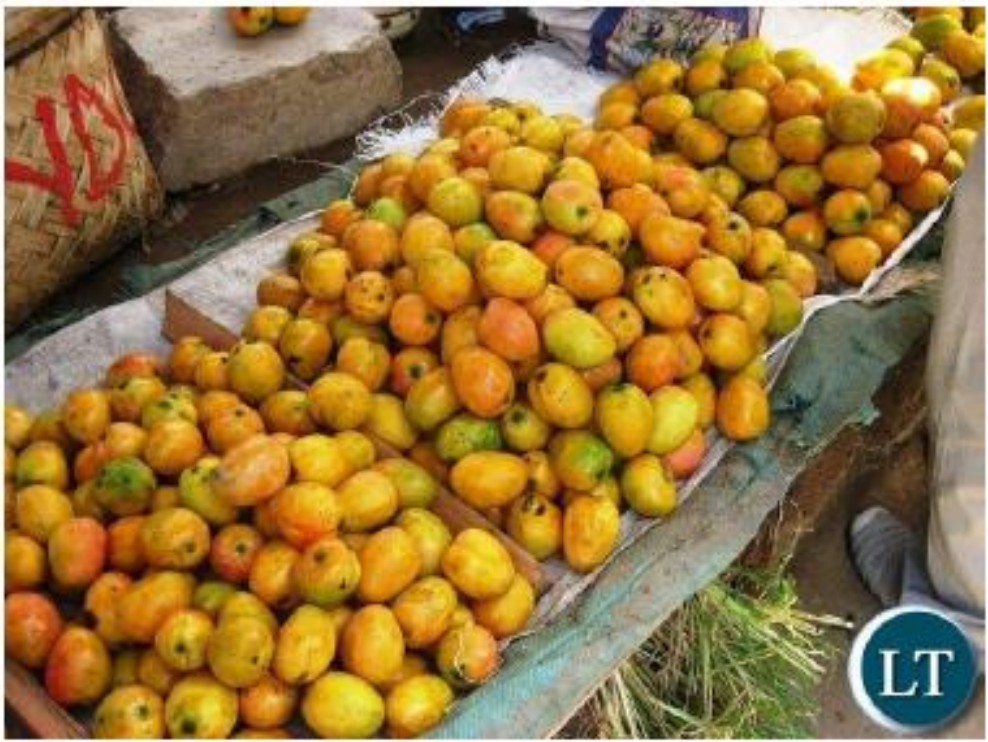

Figure 4. Mango fruit sold without adding value (Courtesy of Lusaka Times)

\section{Acknowledgement}

I want to acknowledge the Almighty God who gives me wisdom and strength to conduct this research. I want also to acknowledge the work done by SAFE Project on Chankwankwa Farms and Food Processors that has given me an insight in the Mango processing industry. The work of the Natural Resources Development College student Mr Dexter Mambwe on the profitability of the mango processing enterprise was of value to my research. I also acknowledge Texila American University Student Mentor Mr Manoj. J. Kumar for his tireless effort to make this research possible. I acknowledge also Mr. Decision Mweemba and Mr. Jeremiah Mweemba who contributed financially towards this research work. I am equally indebted to my family namely Precedence Mweemba and Lweendo Beene who gave me space to work on this paper.

\section{References}

[1]. https://www.businesstoday.in/buzztop/buzztop-feature/...day-mango.../254899.html. 
ISSN: $2520-310 \mathrm{X}$

[2]. http://www.fao.org/fileadmin/user_upload/inpho/docs/Post_Harvest_Compendium__Mango.pdf.

[3]. www.intracen.org/uploadedFiles/intracenorg/Content/About_ITC/Where_are_we_working/Mul ti-country_programmes/Pact_II/National\%20mango\%20study.

[4]. www.sbi.gos.pk/pdf/mango.pdf.

[5]. https://www.entrepreneurindia.co/Document/Download/Project\%20Opportunities\%20in\%20M ango\%20Pulp $\% 20$ Processing\%20Industry\%20(Food\%20\&\%20Agriculture\%20Sector)-208379-.pdf

[6]. https://www.eiriindia.org/Mango_Processing_Canning_Mango_Pulp.html.

[7]. https://allafrica.com/stories/201102140203.html.

[8]. https://www.agrilinks.org/sites/default/files/resource/files/chankwakwa_5.25.17.pdf.

[9]. https://agricultureinzambia.com/.

[10]. Internat. Res. J. agric. Eco. \& Stat.; Vol. 2 (1); (March, 2011).

[11]. Ambika Chauhan et al. / International Journal of Nutrition and Agriculture Research. 1(2), 2014, $93-98$.

[12]. International Journal of Scientific and Research Publications, Volume 3, Issue 2, February 2013 Class notes. 